Arab Univ. J. Agric. Sci., Ain Shams Univ., Cairo, 13(2), 233-248, 2005

\title{
MORPHOLOGICAL AND ANATOMICAL VARIATIONS OF ANABASIS ARTICULATA ECOTYPES IN EGYPT
}

\section{[14]}

\author{
Khafagi, Azza A.F. ${ }^{1}$; A.M.H. Marei ${ }^{2}$ and Sahar K. Mohamed ${ }^{1}$
}

\begin{abstract}
The present study has been carried out on ten stands of Anabasis articulata in Egypt. The relationships between the studied Anabasis articulata stands have been demonstrated as dendrogram based on the morphology, anatomy and some chemical constituents of the plants. Four characteristic ecotypes of Anabasis articulata have been recognized: (i) xerophytic ecotype in the stands of Belbase desert and Sudr El Hytat-Nekhl Road, (ii) xero - halophytiç ecotype in the stands of the Eastern Desert, Sinai Desert, Kattamia-Ain Sukhna Road, Isthmic desert (Fayid), Adabia and Saint Katherine, (iii) halophytic ecotype in the stands of the Red Sea Costal region, Ras Sudr and Hammam Faraon, Sinai and (iv) halo-xerophytic in the stands of the Nekhl-El Hasana and El Hasana-El Quseima Roads. These ecotypes differ, remarkably, morphologically, anatomically and chemically. This may be due to the variation in climatic and soil characteristics of the habitats.
\end{abstract}

Key words: Anabasis articulata, Ecotypes, Morphology and Anatomy.

\section{INTRODUCTION}

Anabasis articulata is a dwarf-shrub, $35-110 \mathrm{~cm}$. Stems woody to half their length or more, erect or tortuous. Branches opposite, with more or less equal internodes, brittle, the older ones with split and peeling bark. Leaves reduced to a short, 2-lobed cupule, villose within. Flowers up to $5 \mathrm{~mm}$, solitary, opposite, the upper arranged in spikes at ends of branches (Boulos, 1999).
About 25 Anabasis species are recorded worldwide in steppes and deserts, mainly in Irano-Turanian and SaharoArabian regions (Zohary, 1966). In Egypt Anabasis L. comprises four species: A. articulata, A. setifera, A. oropediorum and $A$. syriaca (Boulos, 1999). A. articulata and $A$. setifera are widely distributed in all Egyptian deserts, exhibiting adaptability to various habitats, particularly in the halic and xeric ones. While, A. syriaca and A. oropediorum are very limited in their occurrence.

1- Botany Department, Faculty of Science (for Girls), Al-Azhar University, Nasr City, Cairo, Egypt.

2- Botany Department, Faculty of Science, Al-Azhar University, Nasr City, Cairo, Egypt. 
Shalaby (1961) studied the vegetation and phytochemical (saponins) contents of A. setifera and A. articulata collected from nine stands. He stated that Anabasis articulata grows found only rarely in the inner deserts, but was very common in the Coastal Mediteranean desert. According to Fahn (1964), in Anabasis articulate, stems contain some of the most important adaptations of plants to desert life. Fahn (1963), stem assimilants are species with green stems that carry the main burden of photosynthesizing throughout the year. In the articulated Chenopodiaceae, such as Anabasis species, the fleshy photosynthesizing cortex shed from the mature stem in the summer as the result of the formation of a periderm, which develops in the phloem parenchyma. Ahmed and Marzouk (1997) studied Anabasis species collected from Northern Mediterranean Coastal and Sinai using numerical analysis technique. The gross morphology, floral morphology, palynology and seed proteins electrophoresis of the collected specimens were studied. The studied $A$. articulata specimens grouped into two clusters. The first cluster includes specimens collected from middle and south Sinai, while the second cluster includes specimens collected from Mediterranean Coastal Land.

On the other hand, Olowokudejo (1986) stated that the population has become a key word in taxonomy since the inherent variability of species has been accepted as a phenomenon requiring study and appropriate treatment.

Examples of the different ecotypes are given by Stace (1989) who listed cases of physiological ecotypes involving adaptations to differences in soil conditions (e.g. salinity, $\mathrm{pH}$, heavy metals, nutrients and moisture), climate e.g. day length, tem- perature, length of seasons and shade) and biotic influences (e.g. grazing and parasitism).

The present paper presents a detailed morphological, anatomical studies as well as some chemical analysis on ten samples of $A$. articulata collected from different locations of the Egyptian deserts.

\section{MATERIAL AND METHODS}

Five samples of Anabasis articulata were collected from each of the ten stands growing in the three regions (Eastern desert, Isthmic desert and Sinai proper) of Egypt namely: Kattamia - Ain Sukhna Road (50 km. From Cairo), Adabia (Suez - Ain Sukhna Road), Belbase desert, Fayid desert, Ras Sudr site, Hammam Faraon stand, Saint Katherine region, Sudr El -Hytat- Nekhl Road, Nekhl ElHasana Road and El- Hasana El- Quseima Road. All sample were collected during 2000-2003 period.

- The mean values of climatic factors for the ten studied localities (Table 1) were obtained from the Meteorological Department of Egypt for the periods of investigation (2000-2002).

- Soil samples of each studied stand were taken to a depth of $30 \mathrm{~cm}$. The soil moisture content was determined. Soil samples were air-dried, sieved for analysis of soil particles. The total carbonates, the total soluble salts, chlorides, sulphates and $\mathrm{pH}$ value were determined. The methods used in this study are those adopted by Rowell (1994).

- The total ash content in leaves, stems and roots was determined after Brower and Zar (1984). The mineral composition in the plant were es- 
timated following A.O.A.C. (1985) for sodium, potassium, calcium and magnesium contents; and by Lowry (1951); Wall et al (1954) and Dubois et al (1956) for total soluble proteins, total lipid, proline and total carbohydrates contents.

- The morphological and anatomical characteristics of the plant were determined (Tables $3 \& 4$ and Figure 1).
- The relationships between the studied Anabasis articulata specimens have been demonstrated as dendrogram (Fig. 2) by using statistical programs PRIMER (Ver. 5.0). Morphological, anatomical and chemical constituent data of the specimens in the different stands were statistically analysed by means of Euclidean distance using an unweighted pair group method with arithmetic mean (UPGMA).

Table 1. Means of the climatic particulars of five desert regions of Egypt (Meteorology Department, Cairo, 2001-2002).

\begin{tabular}{|c|c|c|c|c|c|}
\hline \multirow{2}{*}{ Regions } & \multicolumn{2}{|c|}{ Temperature in ${ }^{\circ} \mathrm{C}$} & \multirow{2}{*}{$\begin{array}{c}\text { Relative } \\
\text { humidity \% }\end{array}$} & \multirow{2}{*}{$\begin{array}{c}\text { Wind ve- } \\
\text { locity } \\
(\mathrm{km} / \mathrm{hr})\end{array}$} & \multirow{2}{*}{ Rainfall } \\
\hline & Max. & Min. & & & \\
\hline Suez & 45 & 9.2 & $55-69$ & $11-19$ & $0-6$ \\
\hline Cairo & 38.5 & 7.8 & $56-59$ & $5.8-8.4$ & $0-2$ \\
\hline Ismailia & 39.4 & 6.2 & $56-69$ & $4.1-6.3$ & $0-2.4$ \\
\hline Middle Sinai & 27.22 & 13.44 & $78.6-94.2$ & $* *$ & $0-10.2$ \\
\hline Saint Catherine & 34.3 & -2.1 & $* *$ & $5.8-10.1$ & $0-13.6$ \\
\hline
\end{tabular}

\section{RESULTS}

\section{A. Ecological Features}

\section{a - Climate of the studied areas}

There are wide range of temperature and humidity both annual and diurnal. Rainfall is scanty and varies in the different years. Generally the climate of the inner desert areas is of the extremely arid type. However, that of the Mediterranean region is of the semi - arid type.

\section{Cairo area}

The maximum temperature reached $39{ }^{\circ} \mathrm{C}$ in July while the minimum temperature decreased to $7.8{ }^{\circ} \mathrm{C}$ in January and February. The highest rainfall value was recorded in February $(1.7 \mathrm{~mm})$ and the period from June to September was rainless. The maximum relative humidity recorded was $63 \%$ in November and January and the minimum R.H. was $36 \%$ in June. The maximum wind velocity was recorded in May $(8.4 \mathrm{~km} / \mathrm{hr}$.) while the 
minimum value was in November (5.8 $\mathrm{km} / \mathrm{hr}$.)

\section{Ismailia area}

The maximum temperature reached $39.4^{\circ} \mathrm{C}$ in July while the minimum temperature decreased to $6.2^{\circ} \mathrm{C}$ in January. The highest rainfall value was recorded in March $(2.4 \mathrm{~mm})$ and the period from_June to September was rainless. The maximum relative humidity recorded was $68.6 \%$ in November and the minimum R.H. was $55.9 \%$ in April. The maximum wind velocity was recorded in May (6.3 $\mathrm{km} / \mathrm{hr}$.) while the minimum value was in November $(4.1 \mathrm{~km} / \mathrm{hr}$.).

\section{Suez area}

The maximum temperature reached $45^{\circ} \mathrm{C}$ in August while the minimum temperature decreased to $9.2^{\circ} \mathrm{C}$ in January. The highest rainfall value was recorded in February and December $(6 \mathrm{~mm})$ and the period from April to September was rainless. The maximum relative humidity recorded was $69 \%$ in October, November and December while the minimum R.H. was $55 \%$ in May. The maximum wind velocity was recorded in July and September $(19 \mathrm{~km} / \mathrm{hr}$.) while the minimum value was in December $(11 \mathrm{~km} / \mathrm{hr}$.).

\section{Saint Katherine area}

In July the maximum air temperature was $34.3^{\circ} \mathrm{C}$ in August while the minimum temperature was $-2.4{ }^{\circ} \mathrm{C}$ in December. The maximum wind velocity was recorded $(13.2 \mathrm{~km} / \mathrm{hr}$.) in March while the minimum value was in February $(5.8 \mathrm{~km} / \mathrm{hr}$.). It was noticed also that the high rate of rainfall was in October $(13.6 \mathrm{~mm}$.) and rainless in the remainders.

\section{Middle Sinai area}

The maximum temperature reached $27.22^{\circ} \mathrm{C}$ in August while the minimum temperature decreased to $13.44^{\circ} \mathrm{C}$ in December. The highest rainfall value was recorded in January $(10.24 \mathrm{~mm})$ and the period from April to September was rainless. The maximum relative humidity recorded was $94.22 \%$ in January and the minimum R.H. was $78.56 \%$ in June.

\section{b- Soil analysis}

\section{1- Mechanical analysis}

The mechanical analysis of the studied samples showed remarkable differences in soil texture due to differences in soil types (Table 2). The gravel fraction recorded the highest value $(61.6 \%)$ in middle road of Kattamia Ain -Sukhna while it recorded the lowest value $(1.2 \%)$ near Ras-Sudr. Coarse sand fraction was recorded the highest value $(61 \%)$ in Ras Sudr City while it recorded the lowest value $(0.4 \%)$ in Nekhl El-Hasana road. Fine sand fraction recorded the highest value $(52.8 \%)$ in desert of Fayid while it recorded the loweest value $(10.4 \%)$ in Saint Katherine. Silt fraction recorded the highest value $(57.2 \%)$ in Nekhl - ElHasana road while it recorded the lowest value $(2 \%)$ in Saint Katherine and clay fraction recorded the highest value $(41 \%)$ in Sudr El- Hytat-Nekhl road while it recorded the lowest value (1.6\%) in Saint Katherine.

\section{2- Chemical analysis}


Chemical analysis of the different soils showed remarkable variation among 
the studied stands. Moisture content recorded the highest value $(5.26 \%)$ in NekhlEl Hasana- road, while it recorded the lowest value $(0.80 \%)$ in Kattamia Ain Sukhna road (Table 2). The amount of total soluble salts (T.S.S.) recorded the highest value $(4.1 \%)$ in Kattamia - Ain Sukhna road while it recorded the lowest value $(0.1 \%)$ in Sudr El Hytat -Nekhl Road. $\mathrm{pH}$ value was the highest value (9.81) in Sudr El- Hytat- Nekhl Road while it was the lowest value (6.5) Kattamia - Ain Sukhna Road. Organic carbon recorded the highest value $(0.576$ $\%$ ) in Nekhl- El Hasana Road while it recorded the lowest value $(0.012 \%)$ in Belbase \& Fayid desert. Carbonate content recorded the highest value $(59.4 \%)$ near Ras Sudr, Hammam Faraon and Nekhl El-Hasana Road while it recorded the lowest value (12\%) in Saint Katherine. The chloride content recorded the highest value $(1.598 \mathrm{ml} \mathrm{eq} / \mathrm{L})$ in Hammam Faraon while it recorded the lowest value $(0.27 \mathrm{ml} \mathrm{eq} \mathrm{/} \mathrm{L)} \mathrm{in} \mathrm{Hasana} \mathrm{-} \mathrm{El}$ Quseima Road. Sulphate content recorded the highest value $(129.5 \mathrm{ml} \mathrm{eq} / \mathrm{L})$ in Fayid desert while it recorded the lowest value $(5.99 \mathrm{ml} \mathrm{eq} / \mathrm{L})$ in Sudr El -Hytat Nekhl Road. The potassium content recorded the highest value $(29 \mathrm{ml}$ eq $/ \mathrm{L})$ in Kattamia Ain- Sukhna Road $(50 \mathrm{Km}$. From Cairo ) while it recorded the lowest value $(1 \mathrm{ml} \mathrm{eq} / \mathrm{L})$ in Saint Katherine and El -Hasana El-Quseima Road. Sodium content recorded the highest value (240 $\mathrm{ml} \mathrm{eq} / \mathrm{L}$ ) in Kattamia -Ain Sukhna Road (50 km from Cairo) while it recorded the lowest value $(10 \mathrm{ml}$ eq $/ \mathrm{L})$ in $\mathrm{El}$-Hasana El -Quseima Road. Calcium content recorded the highest value $(181.5 \mathrm{ml} \mathrm{eq} / \mathrm{L})$ in Hammam Faraon, while it recorded the lowest value $(3.08 \mathrm{ml} \mathrm{eq} / \mathrm{L})$ in Sudr ElHytat Nekhl Road. Magnesium content recorded the highest value $(131.56 \mathrm{ml}$ eq ( L) in Hammam Faraon, while it recorded the lowest value $(0.66 \mathrm{ml} \mathrm{eq} / \mathrm{L})$ in Adabia.

\section{B- Macromorphology}

The differences between samples of Anabasis articulata are shown in Table (3).

a- Plant Height: There are remarkable and distinct variations in the height of Anabasis articulata growing in different stands. The mean values ranged from $35 \mathrm{~cm}$ in Sudr El HytatNekhl Road to $110 \mathrm{~cm}$ in Adabia (Suez - Ain Sukhna Road).

b- Height/diameter ratio: The ratio ranged from 0.45 to 1.71 . It was very high in the plant growing in El Hasana - El Quseima Road (1.71), while it was low (0.45) in the specimen of Sudr El Hytat- Nekhl Road.

c- The size index of the plant is small $(47.5 \mathrm{~cm}$.) in El Hasana - El Quseima Road and large (140) in Adabia (Suez - Ain Sukhna Road).

d- The stems are erect. They are green in six habitats except in the Fayid desert, Saint Katherine site and El Hasana-El Quseima Road, where they are yellowish green. The internode width ranged from $2-3.5 \mathrm{~mm}$, in the most stands, while reach to $4 \mathrm{~mm}$ in Fayid desert and $4.5 \mathrm{~mm}$ in NekhlEl- Hasana road. The internode length ranged between $8-11 \mathrm{~mm}$, in Adabia, Saint Katherine, Fayid desert, Belbase and El-Hasana 
Arab Univ. J. Agric. Sci., 13(2), 2005 
El-Quseima road and 6-9 $\mathrm{mm}$ in the other sites.

\section{C- Micromorphology}

\section{a- Stem anatomy}

The outline in cross section is terete. Epidermis consists of three-four layers of tangentially with inconspicuous cells. The cuticle layer is thick and smooths (1.5-2 $\mathrm{m} \mu)$. Hypodermis is formed of 1-2 layers of thinner-walled cells, which similarly to the epidermis contain crystals. Cortex is wide $(163.93 \mathrm{m \mu})$, consists of one layer of palisade cells with chloroplasts, forming continuous ring, followed by a layer of sub palisade which is more or less cubical cells and also contain chlorophyll followed by the water-storing parenchyma, which is composed of 6-10 layers containing large druses. Vascular cylinder is composed of 4 bundles; the conducting tissue is well defined. Pith is narrow, homogeneous with thin-walled parenchymatous cells. Druses are very few in the phloem and pith (Fig. 1, 1).

\section{b- Comparative anatomy}

Table (4) presents the differences in stem anatomy of $A$. articulata collected from the nine stands. Cross section area was large $\left(47.12 \mathrm{~mm}^{2}\right)$ in Ras Sudr site and small $\left(18.23 \mathrm{~mm}^{2}\right)$ in Kattamia - Ain Sukhna Road. Epidermal cells were mixed (tangential + radial) in Adabia, Hammam Faraon site and Nekhl - El Hasana Road, while they were tangentially in the other stands. Cuticle layer was thin (0.9-1.2 $\mathrm{m \mu})$ in Belbase desert and Hammam Faraon site and thick (1.5-2) in Fayid desert, Ras Sudr region, KattamiaAin Sukhna Road, Adabia (Suez- Ain Sukhna Road) and Saint Katherine, very thick (2-2.5 $\mathrm{m \mu})$ in the remainder stands. Cortical parenchyma length ranged from $138.54 \mathrm{~m} \mu$ in Sudr El Hytat- Nekhl Road to $231.46 \mathrm{m \mu}$ in Ras Sudr site. Cortical parenchyma consists of 10-12 layers in Belbase desert, Saint Katherine site and El Hasana-El Quseima Road. Vascular bundles were six in Fayid desert, Ras Suder region, Hammam Faraon and Saint Katherine sites; eight bundles in Adabia (Suez - Ain Sukhna Road) but four bundles in the remainders. Meta-xylem vessel was narrow (1.5-2 $\mathrm{m \mu}$ ) in Belbase desert, Saint Katherine site and El Hasana - El Quseima Road and wide (5-6 mu) in Hammam Faraon site. Cortical parenchyma/ Vascular bundle length ratio: the higher value was 12.44, recorded in Hammam Faraon site. The lower value was 6.9, recorded in Sudr El Hytat- Nekhl Road. Pith area: narrow $\left(0.95 \mathrm{m \mu}^{2}\right)$ in Fayid desert and wide $\left(4.73 \mathrm{~m} \mu^{2}\right)$ in Ras Sudr stand.

\section{Chemical constituents}

\section{Preliminary Phytochemical Screening}

A. articulata contains sterols, alkaloids and saponins. Negative results were obtained for tannins and flavonoides. The results are presented in Table (5).

\section{Investigation of plant constituents}

The principal common types of chemical constituents were investigated in $A$. articulata plant in order to compare between their amounts in the ten studied stands. These chemical constituents comprised the elementary compositions $\left(\mathrm{Na}^{+}\right.$, $\mathrm{K}^{+}, \mathrm{Ca}^{++}$and $\mathrm{Mg}^{++}$), total ash contents, total carbohydrates, total soluble proteins, total lipid content and proline content. The results are presented in Table (5). 
Arab Univ. J. Agric. Sci., 13(2), 2005 
Khafagi; Marei and Mohamed

Arab Univ. J. Agric. Sci., 13(2), 2005 
Arab Univ. J. Agric. Sci., 13(2), 2005 


\section{DISCUSSION}

In Egypt Anabasis articulata, has wide ecological amplitudes. It is widely distributed in the Egyptian deserts especially in the Wadis and mountains, it has many growth forms.

The experimental discontinuities in morphological, anatomical characters and chemical constituents demonstrate that the ten stands of $A$. articulata under study contain four ecotypes (Fig. 2) as follows: (i) the xerophytic ecotype growing in Belbase desert and Sudr El Hytat-Nekhl Road. Its cortical parenchyma length /vascular bundle length ratio is small and druses are few. (ii) The xero - halophytiç ecotype of common occurrence in Eastern Desert and Sinai, as Kattamia-Ain Sukhna Road, Fayid desert, Adabia and Saint Katherine stands. It is characterized by the epidermis consisted of four layers. (iii) The halophytic ecotype of wide ecological amplitude growing in the Red Sea Costal region as well as Ras Sudr and Hammam Faraon sites. In these stands: the plant height / diameter ratio is large; the epidermis consisted of three layers, the area of cross section is large, cortical parenchyma is wide and the cortical parenchyma/ vascular bundle length ratio is large. (iv) The halo-xerophytic ecotype occurs in Nekhl-El Hasana and El Hasana-El Quseima Roads. It characterized by large height / diameter ratio and its epidermis consists of three layers.

Upon such different morphological characteristics it could be easy to differentiate between the four ecotypes of Anabasis articulata. The color of the stem (yellowish green or green), plant height vary between the ecotypes. The observed morphological differences be- tween ecotypes have often been attributed to differences in climatic factors (Bjorkman \& Holmgren, 1963 and Cheng \& Chou, 1997), to differences in edaphic factors (Gregor, 1938), or to biotic factors (Gregor and Watson 1954). It is worth mentioning that the anatomical features of stems of the recognized ecotypes exhibited considerable differences, which appear also to be, distinctive. These differences are also the product of adaptive mechanisms to the environment (Emad El-Deen, 1990; Batanouny et al 1991 and Khafagi et al 1996). Therefore the ecotypes are the product of genetic responses of populations to their habitats. Though the different ecotypes of a species are morphologically distinct, yet they are concentrated in one taxonomic species, subspecies and genera. Nevo et al (1998) results confirm our results.

Magnesium and proline are highly affected by the distribution of Anabasis articulata in different habitats followed by total ash, sodium and calcium, potassium, total soluble protein and total soluble carbohydrate. Total lipid showed nonsignificant results. Also the ecotypification of Anabasis articulata not affect on total lipid.

The proline accumulation and degradation reacted sensitively to changing climatic conditions (Treichel et al 1984). El-Ghoneimy et al (1977) emphasized that Anabasis articulata growing naturally in calcareous soils absorbed more $\mathrm{Ca}^{+2}$ and $\mathrm{Mg}^{+2}$ ions keeping the $\mathrm{Na}^{+}$and $\mathrm{Cl}^{-}$ levels in the tissues in a range commonly found in non-halophytic species. The resistance to drought of the plant could be assigned to carbohydrate, protein or alkaloids accumulation (Shalaby et al 1981 and El-Monayeri et al 1981). 


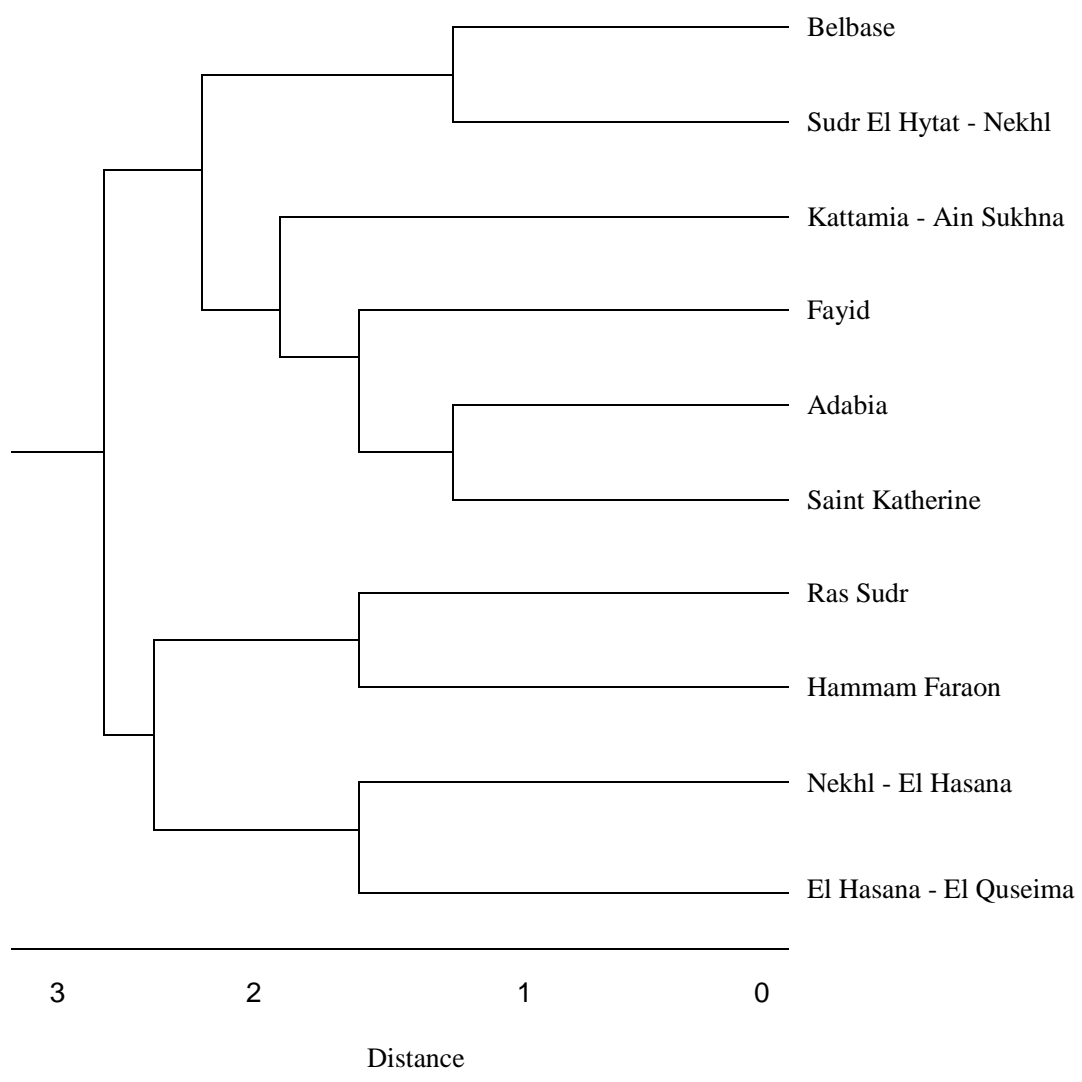

Figure 2. Dendrogram illustrating the relationships between the studied specimens of Anabasis articulata at different stands

From the results of Table (2), soil texture, organic carbon, soil moisture content (as shown in stands Kattamia Ain Sukhna Road, Adabia, Belbase desert, Fayid desert, Ras Sudr, Hammam Faraon, Saint Katherine, Sudr El -HytatNekhl, Nekhl El- Hasana and El- Hasana El- Quseima) these factors clearly indicate remarkable differences in growth forms, in ecotypic formations and distribution of various species in the desert regions as indicated by numerous workers in the field of plant ecology and plant sociology (Abd El-Ghani, 1998 and Marie 1996 \& 2000). While soil salinity and calcium carbonate are the main factors associated with lower species diversity (Abd El-Ghani, 1998). Shalaby (1961) confirmed that the climatic conditions and the soil factors play a prominent role in the constitution and distribution of Anabasis communities.

From the results, it is evident that ecological conditions play an important role 
in the ecotypification of the Anabasis articulata. The four ecotypes differed, (morphologically, anatomically and chemically) from each other depending on the climate-soil interrelations of the habitat. It can be concluded therefore that ecotypes can be recognized on the bases of morphological, anatomical, chemical constituents and genetically as well as on ecological evidences.

As no morphological differences of taxonomical value were found and very few differential physiological characteristics were encountered, the ten stands seem to be at the early stage of ecotypic differentiation.

\section{REFERENCES}

Abd El-Ghani, M.M. (1998). Environmental correlates of species distribution in arid desert ecosystems of Eastern Egypt. Journal of Arid Environments, 38: 297-313.

Ahmed, M.F. and R.I. Marzouk (1997). A Numerical Taxonomic Study on the Genus Anabasis L. (Chenopodiaceae) in Egypt. Desert Inst. Bull. Egypt, 47(1): 187-240.

Association of Official Agricultural Chemists (1985). Official Methods of Analysis. $14^{\text {th }}$ Ed. The A.O.A.C. Washington, D.C. USA.

Batanouny, K.H.; A.H. Hassan and N.A. Sawaf (1991). Ecotypes of Phragmites australis in Egypt. Proc. Intern. Conf. Plant Growth, Drought and Salinity in the Arab Region Cairo Univ. Egypt: 97-114.

Bjorkman, O. and P. Holmgren (1963). Adaptability of the photosynthetic apparatus to light intensity in ecotypes from exposed and shaded habitats. Physiol. Plant, 16: 889-914.

Boulos, L. (1999). Flora of Egypt. Vol. 1 pp. 125-126, (Azollaceae - Oxalidaceae). Al Hadara Publishing, Cairo, Egypt.

Brower, J.E. and J.H. Zar (1984). Field and Laboratory Methods for General Ecology. 226 pp, Wm. C. Brown Publishers, Dubuque, Iowa, USA.

Cheng, K.-T. and C.-H. Chou (1997). Ecotypic variation of Imperata cylindrical populations in Taiwan: 1. Morphological and molecular evidences. Bot. Bull. Acad. Sinica, 38: 215-223.

Dubois, M.; K.A. Gilles; J.K. Hamilton; P.A. Rebers and F. Smith (1956). Colorimetric method for determination of sugars and related substances. Analyt. Chem., 28: 350-356.

El-Ghoneimy, A.A.; A.M. El-Gazzar; A. Wallace and E.M. Romney (1977).. Mineral element composition of the natural vegetation along a transect at mareotis. Egypt. Soil Sci., 124: 16-26.

El-Monayeri, M.O.; M.M. Youssef and A.A. El-Ghamry (1981). Contributions to the Autecology of two Zygophyllum species growing in the Egyptian Desert. Egypt. J. Bot., 24: 49-68.

Emad El-Deen, H.M. (1990). Some Aspects of Drought Resistance Mechanisms of Deserts Plants. pp. 165-166, M.Sc. Thesis Bot. Dept., Fac. Sci., Cairo Univ., Cairo, Egypt.

Fahn, A. (1963). The fleshy cortex of articulated Chenopodiaceae. Maheshwari Comm. Vol. J. Indian Bot. Soc., 42(A): 39-45.

Fahn, A. (1964). Some anatomical adaptations of desert plants. Phytomorphology, 14: 93-102.

Gregor, J.W. (1938). Experimental taxonomy. II. Initial population differentia- 
tion in Plantago maritima L. of Britain. New Phytol., 37: 15-49.

Gregor, J.W. and P.J. Watson (1954). Some observations and reflections concerning the patterns of intraspecific differentiation. New Phytol., 53: 291-300.

Khafagi, A.F.; H. Al-Tantawy; M. ElMonayeri and A. Marei (1996). Anatomical variation in four ecotypes of Zilla spinosa (L.) Prantl. Al-Azhar Bull. Sci., 7(2):1479 -1490.

Lowry, O.H.; N.J. Rosebrough; A.I. Furr and R.J. Randall (1951). Protein measurement with Folin phenol reagent. J. Biol. Chem. 193: 265-275.

Marei, A.H. (1996). Ecotypic Variation of Some Desert Plants Growing in Various Habitats. p. 132, M.Sc. Bot. Dept., Fac. Sci., Menoufiya Univ., Shebeen ElKom, Egypt.

Marei, A.H. (2000). A Model for the Use of GIS Investigation Mapping of a Phytogeographical Region in Egypt. pp. 178-179, Ph.D., Bot. Dept., Fac. Sci., AlAzhar Univ., Cairo.

Nevo, E.; B. Baum; A. Beiles and D.A. Johnson (1998). Ecological correlates of RAPD DNA diversity of wild barley, Hordeum spontaneumn, in the Fertile Crescent. Genet. Resour and Crop Evol., 45: 151-159.

Olowokudejo, J. D. (1986). Variation and Taxonomy of Bicutella valentine in Spain. Can. J. Bot. 27:762-8.
Rowell, D.L. (1994). Soil Science: Methods and Applications. 350 pp. Longman Publishers, Singapore.

Shalaby, A.F. (1961). Ecological and Phytochemical Studies on Anabasis articulata and Anabasis setifera. p. 162, Ph.D. Thesis, Bot. Dept., Fac. Sci., Cairo Univ., Egypt.

Shalaby, A.F.; M.O. El-Monayeri; M.M. youssef and A.A. El-Ghamry (1981). Phytochemical studies on two Zygophyllum species growing in the Egypt desert. Bull. Fac. Sci., Riyad Univ, 13(2): 172-192.

Stace, C.A. (1989). The present and future infraspecific classification of wild plants, pp. 9-20. In: Infraspecific Classification of Wild and Cultivated Plants, Styles, B.T. (Ed), Clarendon Press, Oxford, UK.

Treichel, S.; E. Brinekmann; B. Seheitler and D. J. von Willert (1984). Occurrence and changes of proline content in plants in the southern Namib Desert in relations to increasing and decreasing drought. Planta, 162: 236-242.

Wall, M.E.; M.M. Kreider; C.F. Kemson; C.R. Eddy; J.J. Williaman; D.S. Corell and H.S. Gently (1954). Steroidal sapogenins. VII- Survey of plants for steroidal sapogenins and other constituents. J. Pharm. Soc., 43:1-3.

Zohary, M. (1966). Flora Palaestine Part I. pp. 176-178. The Israel Academy of Science and Humanities, Jerusalem. 
بحلة اتحاد الجامعات العربية للدراسات والبحوث الزراعية، جامعة عين شنم، القاهرة ، 13(2)، 233-248، 2005

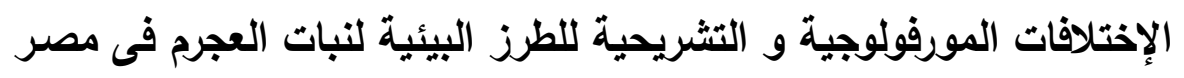

[14]

$$
\begin{aligned}
& \text { عزة أحمد فهمى خفاجى } 1 \text { - عبده حامد مرعى2 - سحر قناوى محمد } 1
\end{aligned}
$$

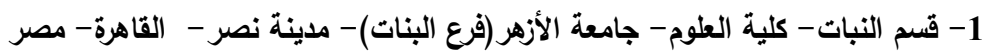

$$
\begin{aligned}
& \text { 2- قسم النبات - كلية العلوم - جامعة الأزهر - مدينة نصر - القاهرة - مصسر }
\end{aligned}
$$

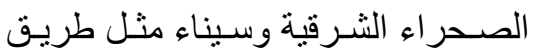

بنيت الدراسة الحاضرة على عشر مواقع

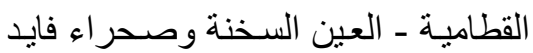

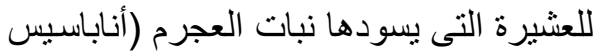
ومنطقة سانت كاترين.

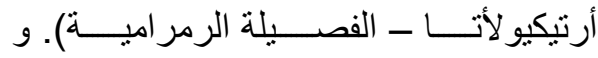
3. الطرز البيئسي الملحى ذو المـدى البيئسي عرضـت العلأقـة بـين عينـات نبـات العجـرم

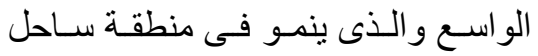

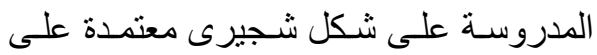

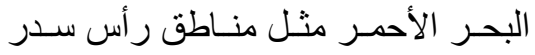

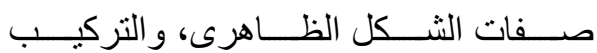
وحمام فر عون. التشريحى و المحتوى الكيميائى.

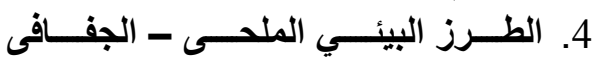

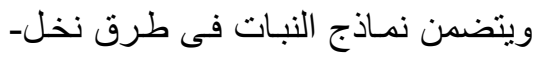

$$
\text { الحسنة و الحسنة - القسيمة. }
$$

أختلفت كل الطرز البيئية، بشكل واضح كل منهم عن الآخر، مورفولوجيا، وتشريحيا وكيميائيا، إعتماد على علاقات التربة و المناخ المتبادلة.

تضمنت العثر عينات لنبات العجى الكيمياسى العرم تحث

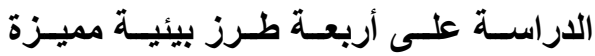
كالتالي 1. الطرز البيئي الجفـافى وينمـو فى منطقة بلبيس و طريق سدر الحيطات - نخل.

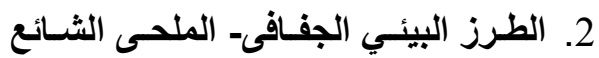

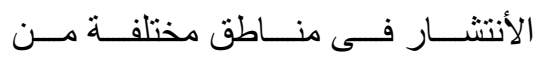

تحكيم: ا.د محمد عبد الرسول محمد

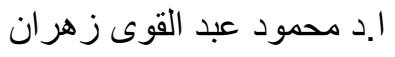

